\title{
THE URDU AND ENGLISH MEDIUM DIVIDE IN PUNJAB, PAKISTAN
}

\author{
Ashiq Hussain \\ Director Public Instruction (Colleges), Higher Education Department, Lahore \\ dpicolleges.hed@gmail.com
}

Asma Amanat*

Assistant Professor, Department of Urdu, Government Islamia Graduate College for Women, Lahore falaqulsama@gmail.com

\begin{abstract}
English and Urdu languages are used in Pakistan as official languages for spoken and written communication. In the education system of Pakistan, a linguistic divide exists, and it divided the Pakistani education system into two streams known as English medium and Urdu medium. In Pakistan, Government schools, colleges, and universities are Urdu medium and offer very low-price education to the poorer and middle-class communities whereas English medium schools, colleges, and Universities are owned by private organizations and offer education to economically well-off societies. The said disparity in the education system created self-identities and linguistic capital. Qualitative methodology and thematic data analysis techniques were used to prepare proper report findings to comprehend how scholars' experiment and make their own opinions keeping in mind the past and present situations of education viz-a-viz social impact of English language learning. In this study, it is also recommended how inequalities and language discrimination can be removed in the government language policies.
\end{abstract}

Keywords: English, Urdu, English-Urdu divide, English learning, Language challenges.

\section{INTRODUCTION}

In Pakistan, more than 74 languages are spoken. In Pakistan, Urdu has been declared as national language under its 1973 constitution. The English language is mostly used for official correspondence. Every administrative office of Pakistan including the army and judiciary uses the English language for correspondence (Mansoor, 2004). The constitution of Pakistan recognizes different regional and provincial languages but has no clear rules and policies regarding their use in the government and private institutions even everyday lift (Manan \& David, 2021). The true picture of the English and Urdu languages is that both are widely used and recognized in Pakistan (Manan \& David, 2014; Rahman, 2008). Both the languages gain their worth in the linguistic market. The Urdu language is used everywhere in Pakistan for communication and speaking and the English language is mostly used in Pakistan for official correspondence (Rahman, 2004). In Higher Education, every book is available in the English language and very few books are available in Urdu. Hence, the English language is the gatekeeper to enter Higher Education (Rahman, 2019). The English language skills are also mandatory to get a high-profile job as well as the English language is also essential for the business community to build their relationships with international stakeholders and also to market their products worldwide (Haidar, 2019; Haidar \& Fang, 2019a). The elite class families, use English language for daily life communication.

In Pakistan, mainly two types of educational systems exist: English Medium private sector Colleges/Universities, and Urdu Medium public sector Colleges/Universities. The private colleges are further divided into two subcategories i.e. elite and non-elite colleges keeping in view their fees structures, infrastructure, atmosphere, and facilities (Tamim, 2021). In Pakistan, only private colleges are offering A/O level schooling and public sector colleges are offering other intermediate programs and affiliate them with the Board of Intermediate and Secondary Education. In Pakistan, the term Urdu and English medium have also become a social status (Darquennes et al., 2020). The elite class

\footnotetext{
${ }^{*}$ Corresponding Author
} 
students get admission in English medium schools only and do not prefer to go Urdu medium schools, whereas the students belonging to middle class and low obtain admissions in Urdu medium colleges due to their financial conditions, but these some students get admission in English medium on scholarship if they are extraordinary, brilliant (Akhtar \& Hussain, 2019; Manan, 2019).

This study aims to discover how the division of English-Urdu medium in the Higher Education of colleges of Punjab, roadblocks to getting academic opportunities, and future opportunities. The next section of the paper is about the literature review and background of the study followed by the methodology applied for this research. Then the next section is about findings on the results and at the end of this paper, the conclusion and future direction are presented.

\section{LITERATURE REVIEW}

The contribution of the languages in education has been debated among educators scholars and scholars in Pakistan Pakistani education policymakers have not been able to accurately define. The contribution of the language in our educational system cannot be undervalued as it is a language in which concepts ideas are made in the college. The interaction between language and thinking requires a comfortable teaching method for the students in the classroom (Bourdieu, 1991). With more than 7000 languages in 256 countries around the globe. Pakistan is a country where indigenous languages are marked by social issues while Urdu and English form an important academic partnership. The widespread urban language situation in Pakistan is often recognized as a learning tool in a country Language is considered a learning tool for educational purposes (Rahman, 2019). Many issues affect a child's efficiency in class, Parents at home reading content at college classroom teachers are the most important influences for each student's academic personality (Kamath et al., 2018). In the current system of nationalities government education policy must address education issues.

The English language is replacing the Urdu language due to its wide use in the Higher Education disciplines and official use in the private and public sector offices. The English language is even used in all civil services, army, and civil courts to supreme courts. English is also a compulsory subject to get admission in the high-level disciplines and essentials for those students who want to complete their study from abroad (Jabeen, 2020).

English is considered as an international language. This language is used by the people to comprehend and express their ideas. English was spoken by the Brits from 1600 to 1900 The British were the first who played an important role in the spread of English language English is still the most common important and mother language of most republics. In numerous cases, English helps people in many ways. In the 20th century, the United States established English as an international language. Most comic books are published in English make it easy for everyone to understand and read Because English is becoming a very popular language. A maximum of the pictures and TV plays are completed in English and are viewed internationally. English is also the language of the world wide web. Most of the online material is in English and most English speakers use it all over the world (Talpur et al., 2021).

In Pakistan, two parallel education systems created a divide between the middle class and elite class students. Private educational institutions are offering more facilities as compared to public sector institutions, hiring highly paid faculty as compared to public sector institutions, offering jobs to their students after completion of the study, offering high-level pieces of training to their teachers, and their medium of instruction is only English language. English is also used in public sector universities to teach Science and Engineering subjects whereas, on the other hand, the Urdu language is used only to teach a low-prestige subjects. The English medium has high fee structure and it is creating a roadblock for middle-class students to enjoy the facilities offered by the private elite class colleges. The English medium colleges where non-elite class students are studying at a low fee are not able to get facilities as elite class English medium students are enjoying (Haidar \& Fang, 2019b).

English plays an important part in our life because it helps us to communicate. It is the key philological for learning any topic around the globe. It is useful for students as they expand their minds develop, emotional skills, and improve their quality of life through employment. In addition, it is an international language and the only means of messaging in many republics. It is also widely used to publish books in poetry and media. Most authors write in English because most readers only know English and can express themselves well in English. 


\section{METHODOLOGY}

Exploratory study and qualitative analysis methods were used to accomplish our research. This research was conducted at large private universities and colleges in Lahore. The universities and colleges have a bilingual language policy whereas the English language is the significant and prominent language for the Engineering and Science fields and Urdu is used in the Urdu department and Political Science, Sociology, and Social work. Various departments used both languages as a medium like the mass communication department.

The participants for this research were selected using a Goal-directed policy. Four types of learners: Ali Haider, a student studying from highly paid elite private and English medium college securing A level track; Usman from middle-class private English medium college securing Intermediate education; Samia from highly paid public sector university securing BSCS degree; and Ruquyya from Urdu Medium public sector college securing ADP track were included.

The interviews of the participants were recorded properly and subsequently analysis of each interview was transcribed. The authors of this paper have a solid grip in English and Urdu. The participants were given free choice to select English, Urdu, or a combination of both languages to answer properly to the authors. The thematic data analysis technique was used to analyze the qualitative data and we identify and analyzed the patterns. The purpose of the thematic analysis is to familiarize the participants with their data, their comments, code of the data, fetch accurate part of the data, finding the theme of the views of the participants. The views of the comments and double were recorded to verify the views of the participants. The transcript of the views was prepared and then send it to the authors for validation.

\section{FINDINGS}

The goal of the study was to investigate the understandings and experiences of the multilingual learners of the private universities and public and private sector colleges in the context of the divide of Urdu English medium of instruction. The consequences of the English-Urdu divide on the current and future of the participants were also investigated. The data we gathered revealed different patterns of higher educational institutions' discriminations and it influenced the future challenges, jobs, and lifestyle. The identified patterns are discussed as under:

\subsection{Students' Observation about their Linguistic Capital}

students' observations about their linguistic capital are devised through the importance consistent with one or extra languages through their interlocutors/audience in extraordinary linguistic markets. Ali Haider and equipped person of the English language think of himself as a trilingual speaker. He stated that all the 03 languages he recognizes Punjabi, English, and Urdu have a great asset price in one-ofa-kind domains and for exclusive functions. Therefore, the English language is a high price advantage for his educational purposes. He has an excessive skill ability in the English language and proves his competence in language informal settings together with elegant negotiations and official examinations. In comparison, Urdu is an excessive price asset for social concord along with bonding with buddies. He is secure the usage of Urdu in oral interplay in informal settings handiest. His mother tongue Punjabi possesses an excessive fee asset for network members of the family.

Usman is less competitive as compared to Ali Haider in English. He is bilingual in his 2 main languages. Usman also thinks that the English language is a highly valuable asset for educationalists and for future job prospects as well as to maintain social status in friends and family. The views of Usman are also like Ali Haider about the Urdu language regarding the value of assets but he negates Ali Haider regarding academic purposes. Usman thinks that the Urdu language is not a low-value language in Pakistan in the context of academic and future life.

Samia's views about the English language are like Ali Haider, she is completing her master's degree in English and Urdu mix medium of instruction from a public sector university. She stated that to meet the degree requirements, the English language is essential for higher studies and jobs. It is also mandatory to learn for publications of the project work. She states that although the English language is the dominant language for educational purposes this language is not to increase the social 
status. Good English language skills can pay you in searching for a good job but the medium of communications in Pakistani organizations is still the Urdu language.

Ruquyya has constrained skill ability in the English language. She has trilingual with Punjab, English, and Urdu. Her major languages for verbal exchange are Urdu and Punjabi. She stated that she is not feeling relaxed while using English, recently, she started to learn the English language as she felt its importance, she is doing this keeping in view her future life. Ruquyya is fluent in Urdu and she can talk different flavors of the Urdu language. The Punjabi language is her mother tongue and she used it to make new friends and keep her buddies. She also speaks the Punjabi language in the family even she often uses Punjabi sentences in the office.

\subsection{Knowledge of English, background schooling, and Self-Concept}

The students think that their current proficiency in the English language is to their inheritance. During an interview with Usman, he stated that:

" I am not able to use the English language efficiently. I often misuse the grammar and I ultimately get the services of my friends to correct my grammar mistakes. It is all due to my poor schooling. If I get better schooling then I will be able to attempt my all annual exam papers in the English language properly"

Usman further explained about schooling that:

"As per my childhood experience, all things depend on the basic schooling. If any student got good schooling then his base will be strong and he can get higher education easily. My friends who got admission to English medium school have a strong grip on English grammar as well as vocabulary. I feel not good when I talk to them in English"

Usman also explained his inner feeling to the authors that he thinks himself as a bad person. He will also feel not good when he will go for Higher and slow learner Education in University as his class-fellows will be fluent in English and he will not. He further stated that when any relative came to his home and try to ask him about his capabilities then I feel that they are talking about my identities.

Similarly, Ruquyya shared her experience:

"I have also received my primary and secondary education from Urdu medium school. I feel easy when I write in English but I am not fluent in English as I am not able to use English words"

Ruquyya further stated that:

"Highly paid English schools are O/A level courses and the parents of poor students are not able to afford such highly paid schools as well as not able to pay the tuition fees to private tutors. My parents belong to a middle-class family and they were not able to afford the dues of the English medium private schools, therefore, I had only one option to get register with Urdu medium school."

Moreover, he stated that our educational system decides our career, if we could get admission in English medium school then parents feel proud and use their admission as a status symbol. Her relatives came into her home and loudly speak about the admission and status of their children and she do not like such talks. If anyone talking in English then everyone respects him and if anyone talking in Urdu then people do not respect him and do not give him preference.

\subsection{Present Experience with Languages}

As stated above, the divide of Urdu-English exists in educational institutions. Ruquyya shared that her college was conducted an admission test in the English language and did not offer the option to the Urdu medium candidates to attempt the test in Urdu. The teachers also discriminate with the Urdu medium students and do not talk with them as they talk with English Medium students. Ali Haider 
and Usman stated that they feel proud that they are getting an education in English and students are different persons. They feel the honor to learn things in English.

Samia who is doing BCS and has an O/A level English background stated that the students who got matriculation and intermediate education have no bright future. It is very hard for them to cross the barriers of the English challenges. She is excellent in English and it empowered her. She feels very comfortable in her social network consisting of A-level students. In addition to this, she wants that she must know about Urdu literature and her friends as well.

\subsection{Learning English for future prospect}

Both Usman and Ruquyya desire to embellish their communication skills in English language. Ruquyya wishes to perform a job as an English teacher as she is very inspired by the English teachers. Ruquyya informed the authors that her mother wants to see me, Master, in English language and also wants to see me as a Lecturer English language in Higher Education Department. Usman wants to improve his English to get admission to the MBBS program, he wants to see him as an expert person in the medical field and for this mission, fluency in English is mandatory as well as reading medical science books. Usman has already gotten extra English classes from a private tutor to improve his English deficiencies.

\section{DISCUSSION}

Over the past two decades, many politicians in Pakistan are working for promotion of English language in institutes both in private and public sector colleges and universities providing equal opportunities for all students. However, realistically speaking, English Urdu Medium is a divide forced on the students by the higher education institutions. As mentioned earlier hashtags in the Urdu and English media in this country have not been the binaries to indicate the teaching medium but more complex structures created and multiplied in two parallel education systems characterized by social class differences and the superiority of learning experiences in general.

The type of college/university becomes an indicator of victory in English skills. And most importantly, this becomes a symbol of a type of person. These diverse characteristics are designed known and maintained in everyday discourse by students themselves their peer's teachers and society in general Students from one academic track such as the Enrollment/Intermediate track have few chances to meet the scholars from other discipline because they think it tough to cross social boundaries. Furthermore your current language capital or English language proficiency appears to be a critical factor in your future goals and lifespan changes.

Findings of the study Pakistan's education system serves as a cultural proliferation agent and supports affluent students increases their probabilities of achievement and suppresses students from marginalized communities. Similarly, because they are socially and economically advanced English capital students will be more likely to take standardized exams and enroll in higher education or a middle-class English Class in this learning. Thus, Urdu English colleges in Pakistan provide facility to the students to get benefit from the system for their bright future.

\section{CONCLUSION AND FUTURE WORK}

It is a bitter reality for all Pakistan citizens that the English-Urdu divide exists in our country. It has been observed that scientists, researchers, academicians, and scholars are not debating and challenging the discrimination and inequalities in our education and opportunities. The decision of using both mediums at the same time is complex as it creates class differences relating to college types. The divide of English and Urdu medium of instruction cannot be mitigated by just selecting one medium of instruction in the college and universities. It is necessary to dig out the things in depth to fill the gap of the medium of instruction and inform the policymakers to take an excellent decision about the medium of instruction in the colleges/institutes of Punjab, Pakistan.

The study also finds out that the divide of English-Urdu prevents poor and middle-class people to get proficiency in English. The social and economical growth of Pakistan also requires linguistic capital. The policies related to languages are directly related to overall economic growth and social growth in Pakistan. After an depth study of the literature and intensive qualitative research, the recommendations of the authors are as under:

1. A comparison analysis is required to be formulated of those countries where the medium of instruction is English and the national language to get a broader picture. 
2. It is necessary to develop one system of education in the light of the vision of the Hon'ble Prime Minister of Pakistan to provide the same facilities and opportunities to every student initially through mother language and then English at the Higher Education level.

3. Teachers who always had a vital role in the development of the nation must be trained to train the trainees in both English and Urdu languages.

4. Special training programs must be arranged at each private and public sector college/university to improve the grammar, structure, and other English and Urdu language relate issues.

5. The policymakers of Education are required to organize special meetings with language experts to prepare future policies on broader issues like English and Urdu literacy skills.

\section{REFERENCES}

Akhtar, U., \& Hussain, B. (2019). An Analysis of Existence of Localization for the Implementation of Triplization in Higher Education Pakistan at Policy and Practice Level. Review of Economics and Development Studies, 5(1), 49-58.

Bourdieu, P. (1991). Language and symbolic power. Harvard University Press.

Darquennes, J., Du Plessis, T., \& Soler, J. (2020). Language diversity management in higher education: Towards an analytical framework. Sociolinguistica, 34(1), 7-29.

Haidar, S. (2019). The role of English in developing countries: English is a passport to privilege and needed for survival in Pakistan. English Today, 35(3), 42-48.

Haidar, S., \& Fang, F. (2019a). Access to English in Pakistan: A source of prestige or a hindrance to success. Asia Pacific Journal of Education, 39(4), 485-500.

Haidar, S., \& Fang, F. (Gabriel). (2019b). English language in education and globalization: A comparative analysis of the role of English in Pakistan and China. Asia Pacific Journal of Education, 39(2), 165-176.

Jabeen, S. (2020). Language planning and policy, and the medium of instruction in the multilingual Pakistan: A void to be filled. International Journal of Multilingualism, O(0), 1-18. https://doi.org/10.1080/14790718.2020.1860064

Kamath, S., Kamath, R., \& D'Souza, B. (2018). An overview of systematic linguistic genocide in Pakistan. International Journal of Civil Engineering and Technology, 9(13), 1691-1697.

Manan, S. A. (2019). Myth of English teaching and learning: A study of practices in the low-cost schools in Pakistan. Asian Englishes, 21(2), 172-189.

Manan, S. A., \& David, M. K. (2014). Mapping ecology of literacies in educational setting: The case of local mother tongues vis-à-vis Urdu and English languages in Pakistan. Language and Education, 28(3), 203-222.

Manan, S. A., \& David, M. K. (2021). Deprescriptivising folk theories: Critical multilingual language awareness for educators in Pakistan. The Language Learning Journal, 49(6), 668-685.

Mansoor, S. (2004). The status and role of regional languages in higher education in Pakistan. Journal of Multilingual and Multicultural Development, 25(4), 333-353.

Rahman, T. (2008). Language policy and education in Pakistan. Encyclopedia of Language and Education, 1, 383-392.

Rahman, T. (2019). Mother tongue education policy in Pakistan. In The Routledge international handbook of language education policy in Asia (pp. 364-380). Routledge.

Rahman, T. (2004). Language policy and localization in Pakistan: Proposal for a paradigmatic shift. 99(2004), 1-19.

Talpur, Q., Kakepoto, I., \& Jalbani, K. B. (2021). Perspectives on College Students Demotivation Factors for Learning English Language. European Online Journal of Natural and Social Sciences, 10(1), 185-194.

Tamim, T. (2021). Language, Class, and Education: Deconstructing the Centre to Rethink Inclusivity in Education in Pakistan. Cogent Education, 8(1), 1897933. 